\title{
Benthic foraminiferal oxygen isotope offsets over the last glacial-interglacial cycle
}

\author{
Babette Hoogakker, ${ }^{1}$ Henry Elderfield, ${ }^{1}$ Kevin Oliver, ${ }^{2}$ and Simon Crowhurst ${ }^{1}$ \\ Received 6 October 2009; revised 12 May 2010; accepted 23 August 2010; published 24 December 2010.
}

[1] The oxygen isotope $\left(\delta^{18} \mathrm{O}\right)$ offset between contemporaneous benthic foraminiferal species is often assumed constant with time and geographic location. We present an inventory of benthic foraminiferal species $\delta^{18} \mathrm{O}$ offsets from the major ocean basins covering the last glacial-interglacial cycle, showing that of the twenty down-core records investigated, twelve show significant temporal changes in $\delta^{18} \mathrm{O}$ offsets that do not resemble stochastic variability. Some of the temporal changes may be related to kinetic fractionation effects causing deglacial/ interglacial enrichment or glacial depletion in mainly infaunal species, but additional research is needed to confirm this. In addition to stratigraphic implications the finding of temporally varying offsets between coexisting benthic foraminiferal species could have implications for sea level, deepwater temperature, and regional deepwater $\delta^{18} \mathrm{O}$ estimates.

Citation: Hoogakker, B., H. Elderfield, K. Oliver, and S. Crowhurst (2010), Benthic foraminiferal oxygen isotope offsets over the last glacial-interglacial cycle, Paleoceanography, 25, PA4229, doi:10.1029/2009PA001870.

\section{Introduction}

[2] Because of the varying occurrence and abundance of individual benthic foraminiferal species in relation to changing environmental conditions, many paleoceanographic studies are not able to use a single benthic foraminifera species to create continuous oxygen isotope $\left(\delta^{18} \mathrm{O}\right)$ records. In order to generate continuous records, composite records are generated, taking into account isotope offsets between different coexisting species. An important assumption, often made, is that such offsets are constant with time and geographical location.

[3] At the same oceanic location coexisting benthic foraminiferal species often have different $\delta^{18} \mathrm{O}$, making it unlikely that all species form their calcite in equilibrium with seawater [Duplessy et al., 1970]. For example, some authors have suggested that the $\delta^{18} \mathrm{O}$ of Uvigerina peregrina reflects $\delta^{18} \mathrm{O}$ equilibrium [Shackleton, 1974; Woodruff et al., 1980; McCorkle et al., 1990], whereas use of a more recent inorganic $\mathrm{CaCO}_{3}$ temperature- $\delta^{18} \mathrm{O}$ fractionation curve [Kim and O'Neil, 1997] suggests that Cibicidoides $\delta^{18} \mathrm{O}$ is in equilibrium with seawater whereas Uvigerina $\delta^{18} \mathrm{O}$ is not [Bemis et al., 1998].

[4] Additional secondary factors that influence benthic foraminiferal $\delta^{18} \mathrm{O}$ include (1) kinetic fractionation effects during hydration and hydroxylation of $\mathrm{CO}_{2}$ related to carbonate chemistry [Spero et al., 1997; Bijma et al., 1999; Zeebe, 1999], (2) metabolic fractionation effects during \footnotetext{
UK.

${ }^{1}$ Department of Earth Sciences, University of Cambridge, Cambridge,

${ }^{2}$ Southampton School of Ocean and Earth Sciences, University of Southampton, Southampton, UK.
}

Copyright 2010 by the American Geophysical Union. 0883-8305/10/2009PA001870 biomineralization related to species specific vital effects [Duplessy et al., 1970; Shackleton, 1974; Schmiedl and Mackensen, 2006], and (3) preservation effects related to dissolution and respiration [Broecker and Peng, 1982; Mackensen et al., 1993; Schmiedl and Mackensen, 2006].

[5] Important assumptions in many paleoceanographic studies are that the $\delta^{18} \mathrm{O}$ offset between inorganic calcite precipitated in equilibrium [e.g., see Kim and O'Neil, 1997] and benthic foraminiferal calcite is constant, and that the offset between the $\delta^{18} \mathrm{O}$ of coexisting benthic foraminiferal species is constant. Here we monitor benthic foraminiferal $\delta^{18} \mathrm{O}$ offsets between commonly used benthic foraminiferal species by comparing the isotope data obtained from coexisting species over the last glacialinterglacial cycle. Additionally we compare down-core $\delta^{18} \mathrm{O}$ offset records with coexisting $\delta^{13} \mathrm{C}$ records to explore whether down-core $\delta^{18} \mathrm{O}$ offset variations may be related to kinetic fractionation effects through changes in organic matter fluxes/decomposition [Fontanier et al., 2006; Schmiedl and Mackensen, 2006].

\section{Material and Method}

[6] This study forms part of a data synthesis effort to improve links between proxy data and mechanistic understanding through Earth system models (http://researchpages. net/QQ), and is largely based on isotope data obtained from data repositories (PANGAEA, NCDC, DELPHI) measured by various laboratories. By using isotope data measured by different laboratories we cannot entirely exclude interlaboratory offsets such as from cleaning, sample size, standards and equipment used, etc. However, for most of the down-core records stable isotope analysis on coexisting benthic foraminiferal species were performed at the same laboratory, thus allowing species-species comparison. 


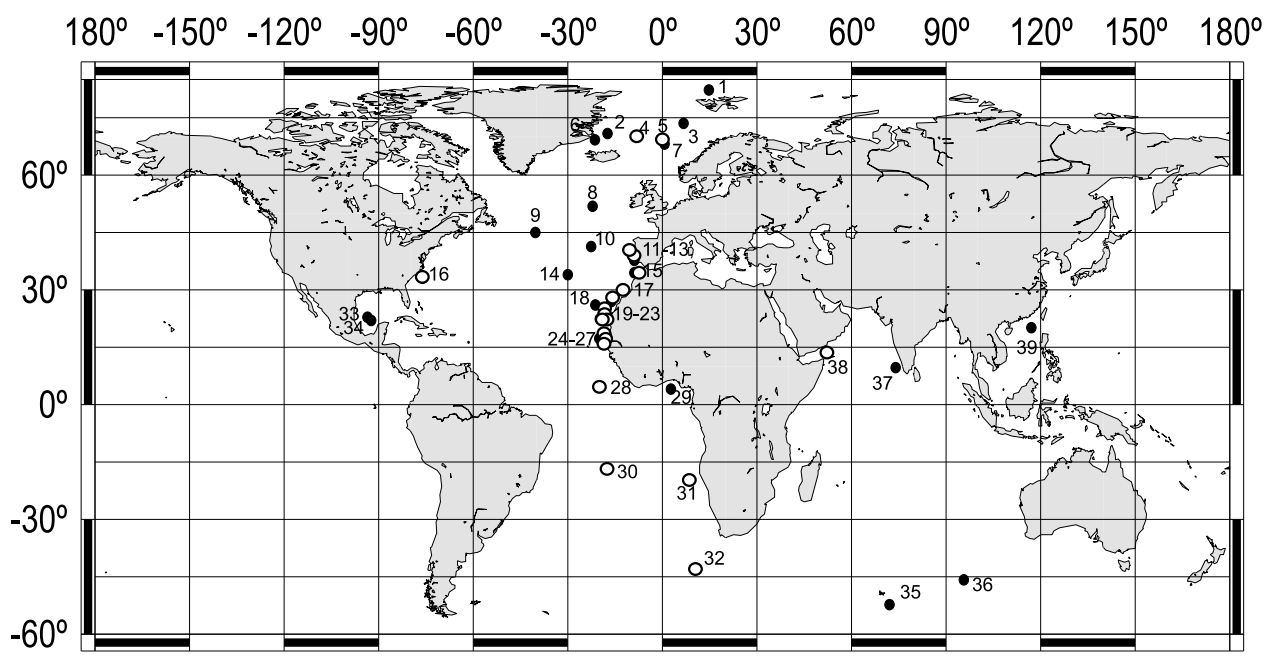

Figure 1. Location details of benthic foraminiferal isotope records used in this study, with 1, PS2212-3; 2, PS1730-2; 3, V27-60; 4, PS1243-1; 5, GIK23065-3; 6, PS2644-5; 7, V27-86; 8, SU90-39; 9, SU90-11; 10, CH72-02; 11, MD95-2042; 12, MD99-2339; 13, GIK11944-2; 14, CH74-227; 15, GIK15666-6; 16, KNR140-2 JPC-37; 17, GIK16006-1; 18, GIK15637-1; 19, GIK12309-2; 20, GIK12392-1; 21, GIK12379-1; 22, GIK16030-1; 23, GIK12328-5; 24, GIK13289-2; 25, GIK12347-2; 26, GIK16402-2; 27, GIK13239-1; 28, GIK13519-1; 29, GIK16856-2; 30, INMD-115BX; 31, V29-135; 32, TTN057-6; 33, TR126-29; 34, TR126-23; 35, MD84-560; 36, MD88-770; 37, MD77-194; 38, GeoB3004-1; 39, GIK17940-2 [Bauch et al., 2001; Berger et al., 1985; Bühring, 2001; CLIMAP Project Members, 1981; Curry et al., 1988; Duplessy, 1996; Duplessy et al., 1988; Hagen and Keigwin, 2002; Hodell et al., 2003; Labeyrie and Duplessy, 1985; Labeyrie et al., 1995, 1996; Sarnthein et al., 2001; Voelker et al., 1998, 2006; Vogelsang, 1990; Wang et al., 1999; Weinelt, 1993; Winn et al., 1991; Wollenburg et al., 2001; Zahn-Knoll, 1986; Zahn et al., 1986]. Map was made using the online map creation Web site http://www.aquarius.geomar.de.

[7] Down-core benthic foraminiferal $\delta^{18} \mathrm{O}$ (and $\delta^{13} \mathrm{C}$ ) data were assembled for records containing multiple species $\delta^{18} \mathrm{O}$ (a total of 39 records) for the last 150,000 years containing data for thirteen species (Cibicidoides/Planulina/Fontbotia wuellerstorfi, here referred to as $C$. wuellerstorfi, Cibicidoides kullenbergi, Cibicidoides pachyderma, Cibicides lobatulus, Planulina ariminensis, Oridorsalis umbonatus, Oridorsalis tener, Uvigerina excellens, Uvigerina hollicki, Uvigerina mediterranea, Uvigerina peregrina, Melonis barleeanum, Globobulimina affinis). Core locations are shown in Figure 1, and details of latitude, longitude, water depth, and benthic foraminiferal species are listed in the auxiliary material (Table S1 in Text S1). Currently available information on habitat requirements of specific benthic foraminiferal species is summarized in the auxiliary material (Table S2 in Text S1).

\section{Results}

[8] Histograms of benthic foraminiferal $\delta^{18} \mathrm{O}$ offsets (epifaunal minus infaunal and infaunal minus deeper infaunal) were plotted for five benthic foraminiferal pairs (C. wuellerstorfi versus U. peregrina, U. hollicki, M. barleeanum, G. affinis and U. peregrina versus G. affinis) combining between 2 and 14 down-core records with a total of at least 100 data points (Figure 2a). Offsets of the remaining benthic foraminiferal sets can be found in the auxiliary material (Figure S1 in Text S1). ${ }^{1}$ A summary of mean benthic foraminiferal $\delta^{18} \mathrm{O}$ offsets for all benthic foraminiferal pairs is provided in Table 1 . The calculated average benthic foraminiferal $\delta^{18} \mathrm{O}$ offsets agree well with those reported in the literature [e.g., Shackleton et al., 2000; Schmiedl and Mackensen, 2006] (Figure 2a and Table 1). Mean benthic foraminiferal $\delta^{18} \mathrm{O}$ offsets are generally lowest (close to 0\%) for epifaunal species pairs (for example $C$. lobatulus versus $C$. pachyderma and $C$. wuellerstorfi versus $C$. kullenbergi; however, we note the different $\delta^{18} \mathrm{O}$ offset between $C$. wuellerstorfi versus $P$. ariminensis $(0.43 \%))$, and highest between epifaunal and deep infaunal species (e.g., $C$. wuellerstorfi versus $G$. affinis $(-0.90 \%))$ (Table 1 and Figure 2a). Offsets between epifaunal $C$. wuellerstorfi and infaunal $M$. barleeanum, for which the majority (85\%) of samples are from Arabian Sea core GeoB-3004-1, are relatively low with a mean of $-0.18 \%$ o (Table 1 ).

[9] Scatterplots of the five benthic foraminiferal sets (the remaining sets can be found in auxiliary material Figure S1 in Text S1) show significant correlations between $C$. wuellerstorfi versus G. affinis, U. hollicki, $U$. peregrina and M. barleeanum $\delta^{18} \mathrm{O}$, which is confirmed by Student $\mathrm{t}$ distribution tests (Figure $2 \mathrm{~b}$ and auxiliary

\footnotetext{
${ }^{1}$ Auxiliary materials are available in the HTML. doi:10.1029/ 2009PA001870.
} 

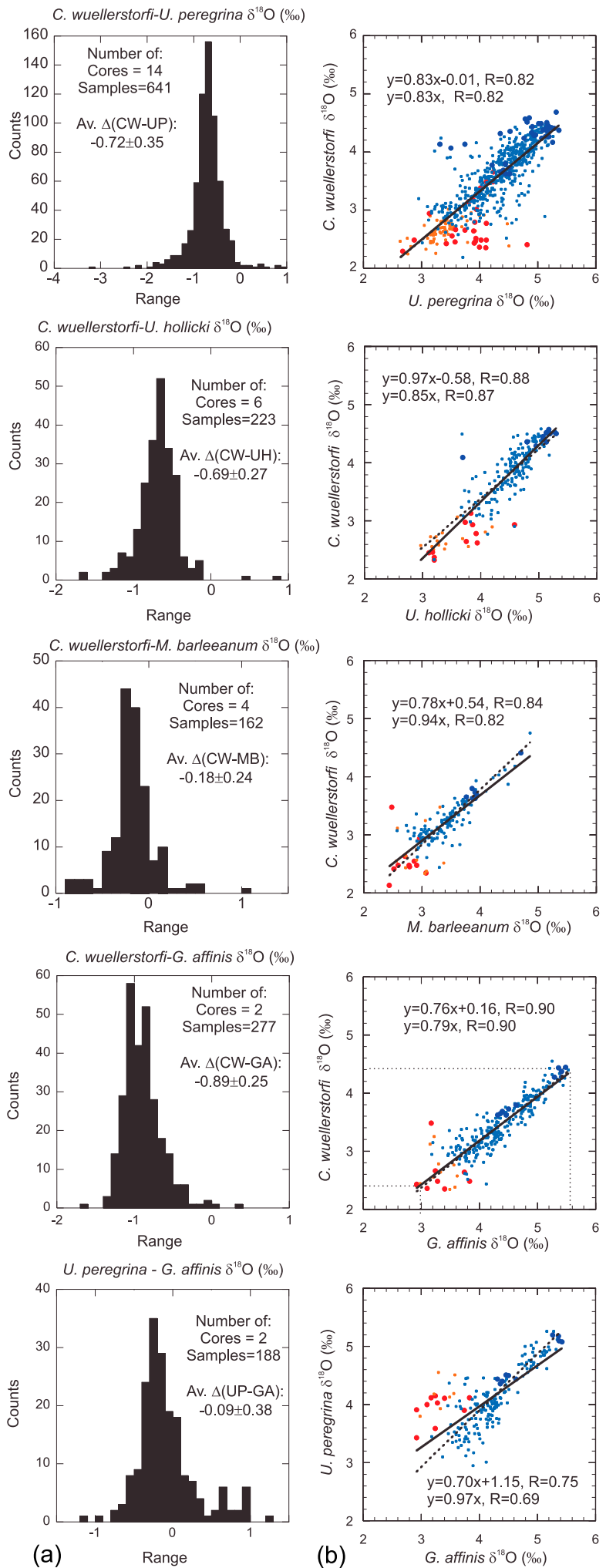

MIS $5(115-126 \mathrm{ka})$

- Holocene (0-10 ka)

- Glacial (18-21 ka)

- Rest material Table S3 in Text S1). However, for C. lobatulus versus $C$. pachyderma, $C$. wuellerstorfi versus $P$. ariminensis, $C$. wuellerstorfi versus $U$. excellens, and $U$. peregrina versus M. barleeanum $\delta^{18} \mathrm{O}$ correlations are weak $(\mathrm{R}<0.6)$, whereas $C$. wuellerstorfi versus $O$. tener and $U$. mediterranea $\delta^{18} \mathrm{O}$ are not significantly correlated (auxiliary material Figure S1 and Table S3 in Text S1). The isotopic ranges of closely correlated benthic foraminiferal species $\delta^{18} \mathrm{O}$ are similar, except for $C$. wuellerstorfi (2.1\%o) versus G. affinis $(2.6 \%$ ) (Figure 2b).

[10] Of all the cores investigated, twenty (indicated in Figure 1 with open circles) contained sufficient data $(>15$ sample pairs) and well-constrained age models for the last $<150,000$ years to compare interspecific $\delta^{18} \mathrm{O}$ offsets for specific stratigraphic time windows. In Figure 3, six examples are shown of records with epifaunal and infaunal benthic foraminiferal $\delta^{18} \mathrm{O}(C$. wuellerstorf $i$ versus $U$. peregrina and $U$. hollicki) and their offsets. Plots of all other down-core records can be found in auxiliary material Figure S2 in Text $\mathrm{S} 1$. Offsets are plotted against depth (m) down-core and significant climatic intervals are marked (Figure 3 ). Where available, AMS ${ }^{14} \mathrm{C}$ ages are plotted. We split the benthic foraminiferal $\delta^{18} \mathrm{O}$ offset records into records that show no temporal variations (Figure $3 \mathrm{a}$ ) and records that show small $(0.2$ to $0.5 \%$ o $)$ to large $(>0.5 \%)$ temporal variations of $\delta^{18} \mathrm{O}$ offsets (Figures $3 b$ and $3 c$ ). Only cores where offset variations exceed the standard deviation of the offset were classified as having temporal variations. Of the twenty cores, twelve were classified as having temporal variations in benthic foraminiferal $\delta^{18} \mathrm{O}$ offsets. Of the benthic foraminiferal $\delta^{18} \mathrm{O}$ pairs (for several cores isotope data was available for more than two benthic foraminiferal species) a total of sixteen to seventeen out of twenty nine pairs showed temporal variations in their offsets (Figure 3 and auxiliary material Figure S2 in Text S1).

[11] In Figure 4 we compare the benthic epifaunalinfaunal foraminiferal $\delta^{18} \mathrm{O}$ offset records of Figure 3 with

Figure 2. (a) Histograms showing benthic foraminiferal $\delta^{18} \mathrm{O}$ offsets for $C$. wuellerstorfi versus $U$. peregrina (CW-UP), U. hollicki (CW-UH), M. barleeanum (CW-MB), $G$. affinis (CW-GA), and $U$. peregrina versus $G$. affinis (UP-GA). (b) Crossplots of the same benthic foraminiferal pairs. Holocene $(0-10 \mathrm{ka})$ samples are indicated with small orange circles, MIS 5e samples are indicated with large red circles, and glacial samples are indicated with small blue circles (full glacial samples $(18-21 \mathrm{ka}$ ) are indicated with big dark blue circles). Normal linear interpolations through the data are shown in black lines, whereas linear interpolations forced through the origin are shown in black stippled lines. Crossplots and histograms for remaining benthic foraminiferal pairs with less data points $(<100)$ or from only 1 down-core record can be found in auxiliary material Figure S1 in Text S1. For the correlations either a normal linear correlation or a linear correlation through 0,0 produces similar correlation coefficients $(\mathrm{R})$ for the data sets. However, in sets where the correlation is weaker, a linear correlation through 0,0 gives a much lower R (Figure S1 in Text S1). 


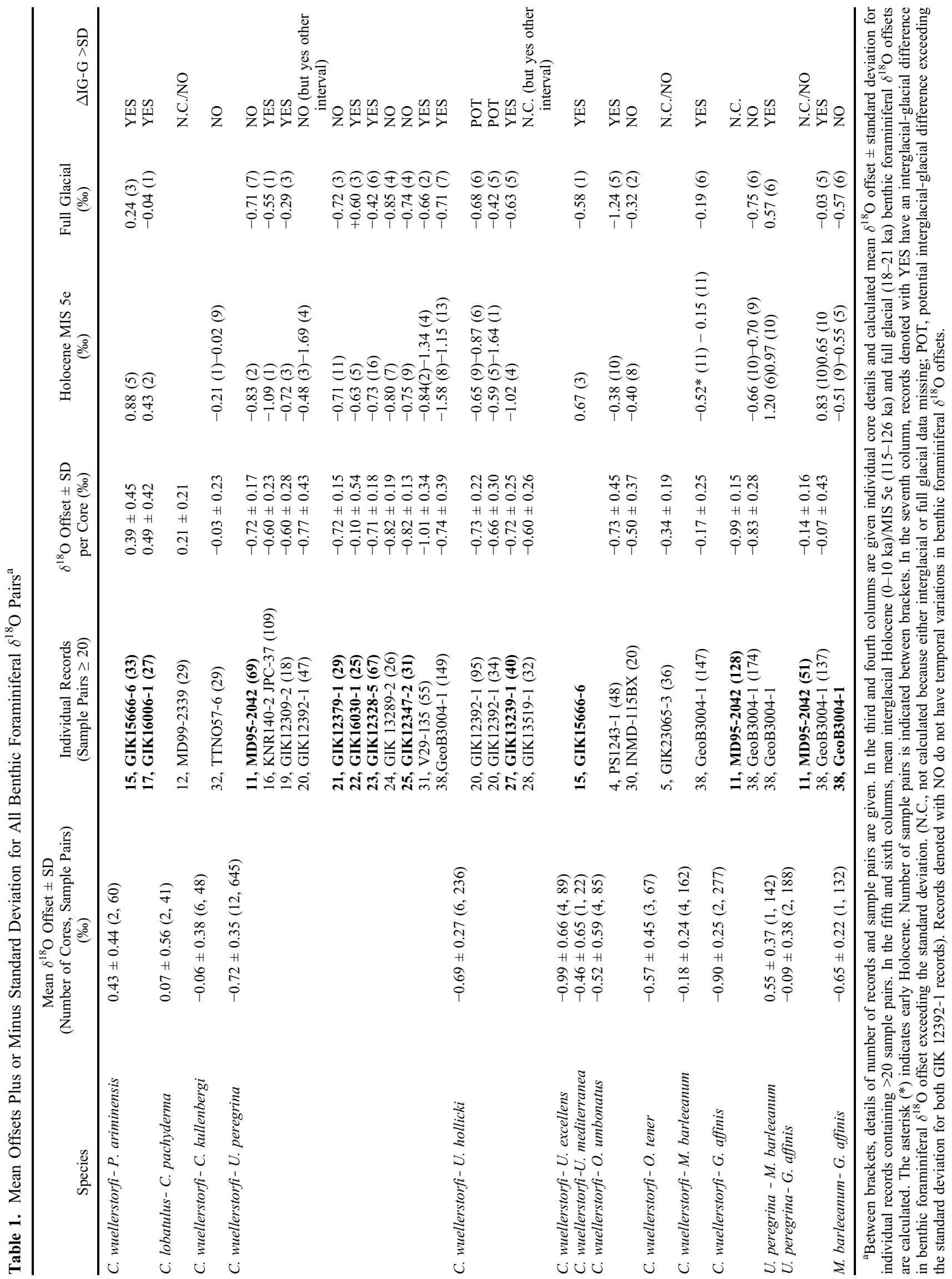


a, no temporal variations in benthic foraminiferal $\delta^{18} \mathrm{O}$ offset
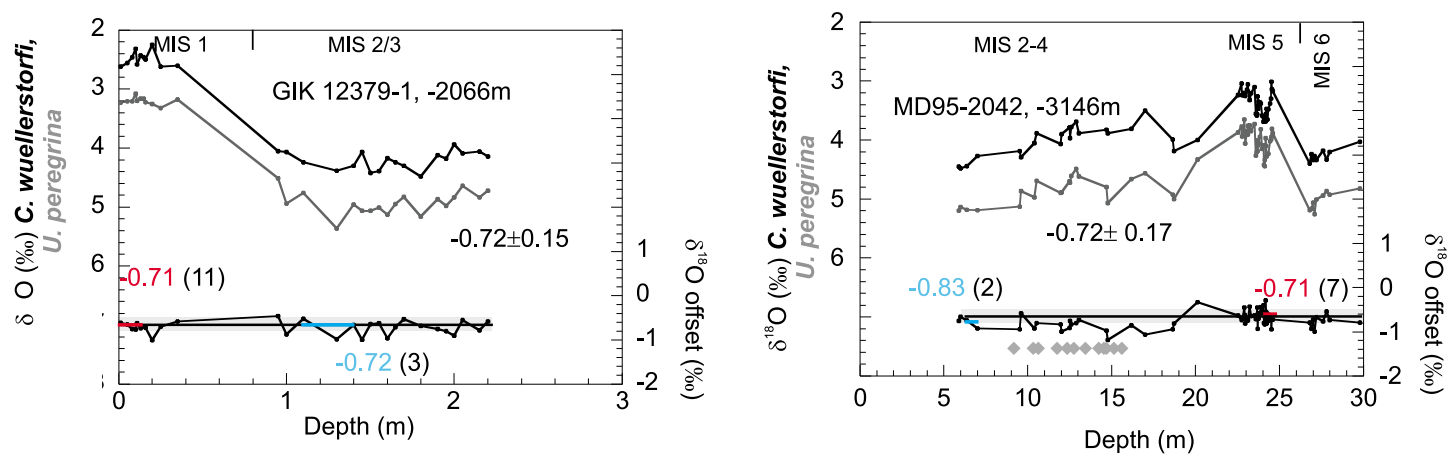

b, small temporal variations in benthic foraminiferal $\delta^{18} \mathrm{O}$ offset $(0.2$ to $0.5 \%)$
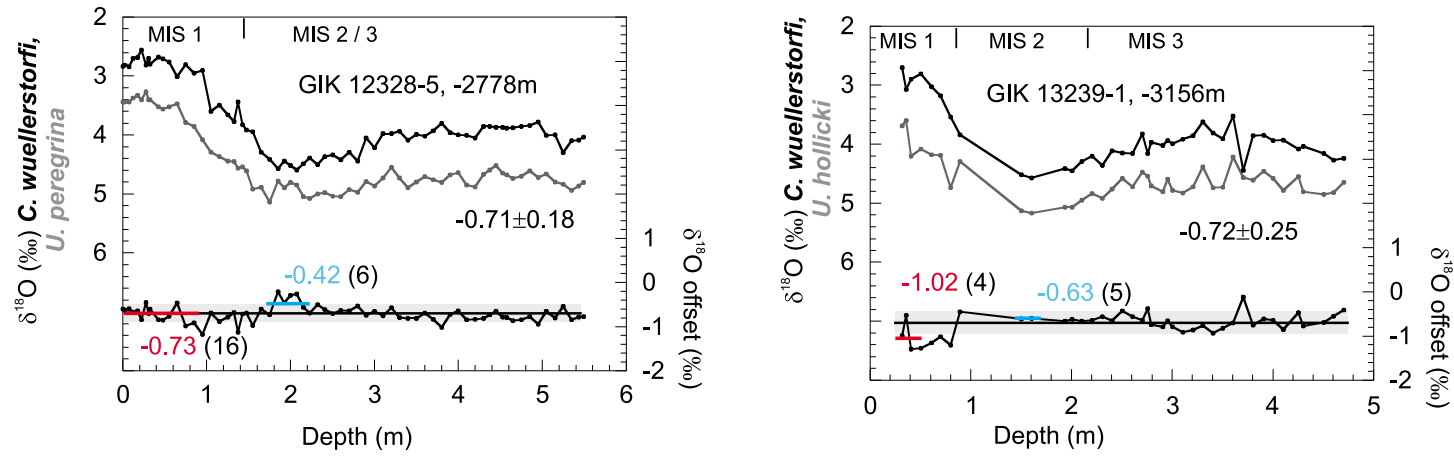

C, large temporal variations in benthic foraminiferal $\delta^{18} \mathrm{O}$ offset $(>0.5 \%)$
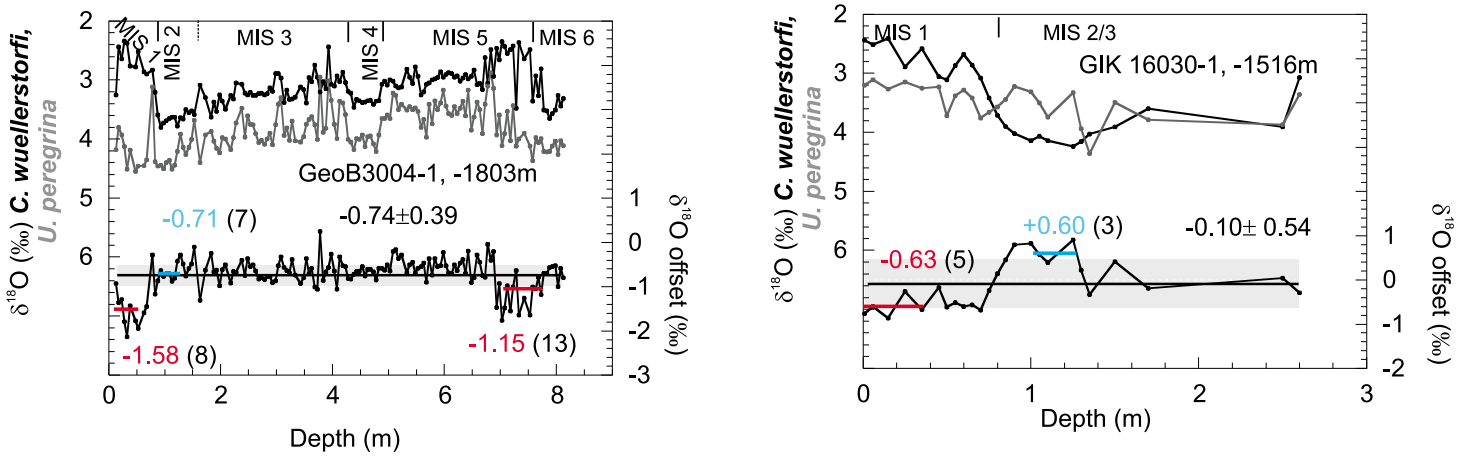

Figure 3. Examples of individual benthic foraminiferal $\delta^{18} \mathrm{O}$ records (top of each plot; epifaunal in black, infaunal in gray) and offset records (bottom of each plot). Where available, locations of AMS ${ }^{14} \mathrm{C}$ ages or calendar ages are projected as gray diamonds or gray boxes. Major isotope stages (after SPECMAP) are indicated at the top. Black straight lines represent the mean record $\delta^{18} \mathrm{O}$ offsets, with gray background boxes delineating the standard deviation. Offsets are plotted against depth $(\mathrm{m})$ rather than age to minimize the role of interpretation with regards to age models and to emphasize extent of depths with varying isotope offsets involved. Benthic foraminiferal oxygen isotope offset records are divided into three categories: (a) records showing no temporal variations in benthic foraminiferal $\delta^{18} \mathrm{O}$ offset, (b) records showing small $(0.2-0.5 \%$ ) temporal variations in benthic foraminiferal $\delta^{18} \mathrm{O}$ offset, and (c) records showing large $(>0.5 \% 0)$ temporal variations in benthic foraminiferal $\delta^{18} \mathrm{O}$ offset. All other records can be found in auxiliary material Figure S2 in Text S1. Data are from Sarnthein et al. [1994], Shackleton et al. [2000], and Schmiedl and Mackensen [2006]. AMS ages MD95-2042 (19600 to $46400{ }^{14} \mathrm{C}$ years with 500 year reservoir correction) are from Shackleton et al. [2004]. Also indicated are averaged interglacial (Holocene 0-10 ka; MIS 5e 115-126 ka) benthic foraminiferal offsets in red and full glacial (18-21 ka) benthic foraminiferal offsets in blue. Only cores where offset variations exceed the standard deviation of the offset were classified as having temporal variations. 


\section{a, no temporal variations in benthic foraminiferal $\delta^{18} \mathrm{O}$}
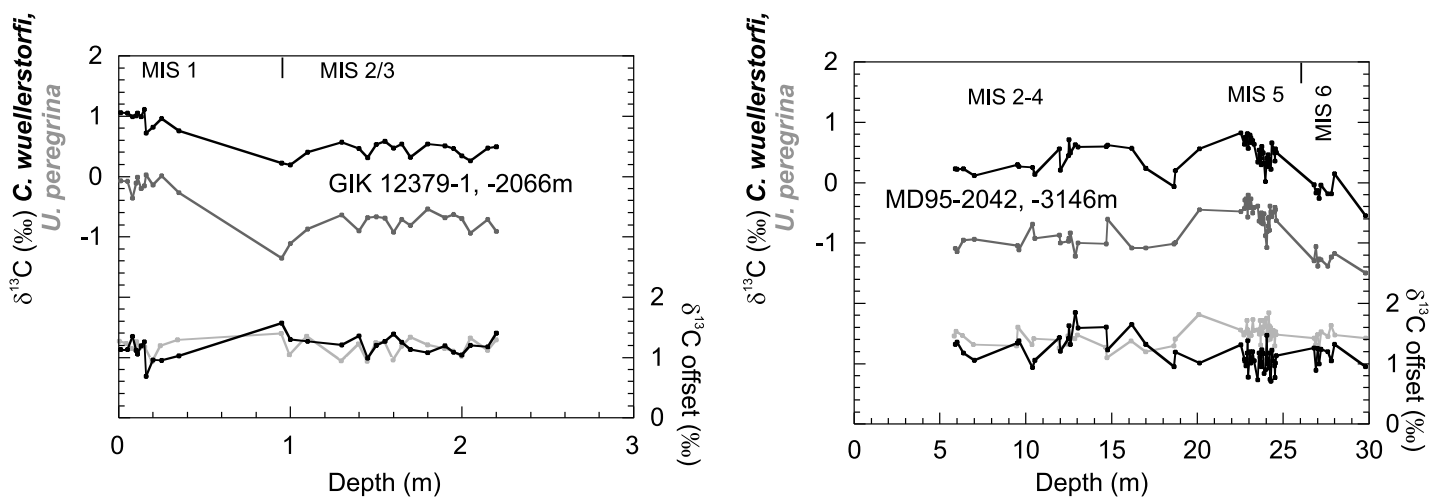

b, small temporal variations in benthic foraminiferal $\delta^{18} \mathrm{O}(0.2$ to $0.5 \%)$
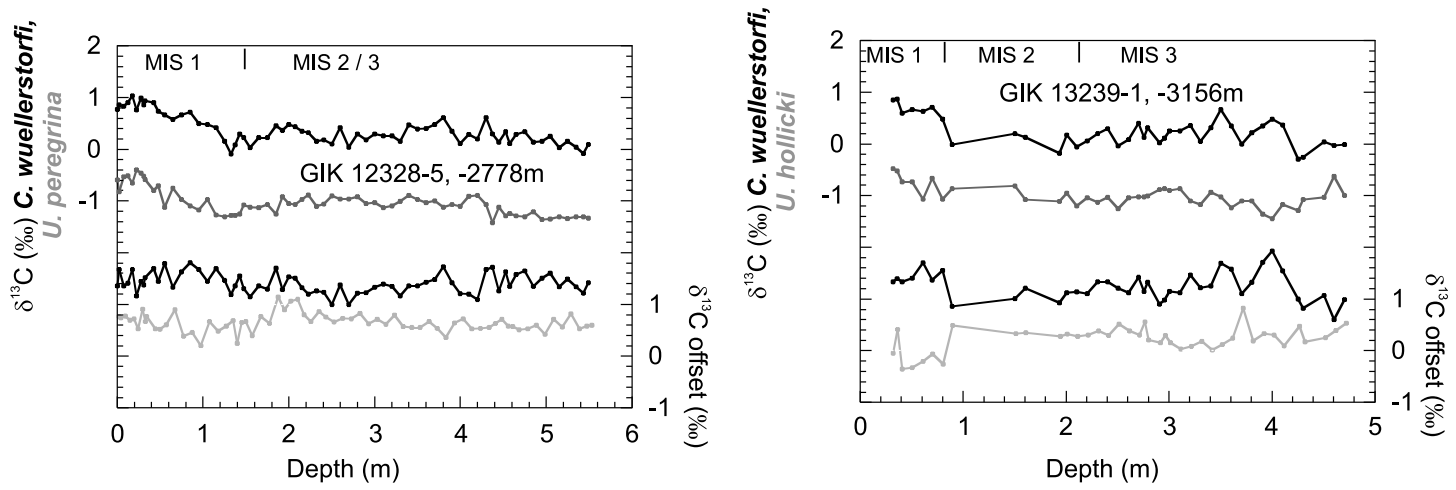

c, large temporal variations in benthic foraminiferal $\delta^{18} \mathrm{O}(>0.5 \%)$
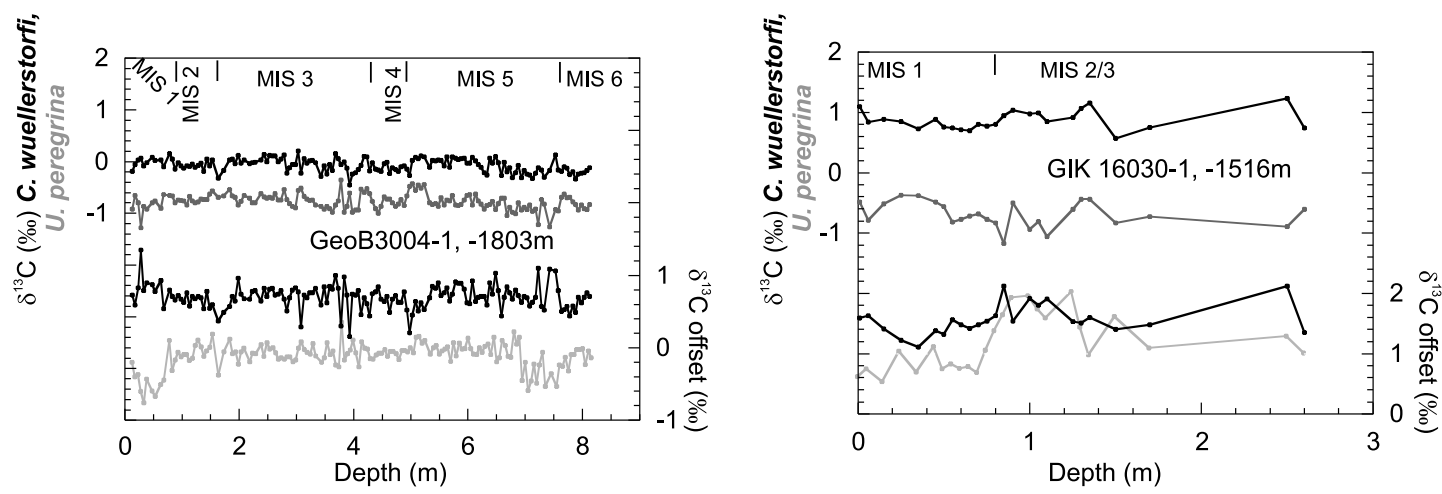

Figure 4. Epifaunal and infaunal benthic foraminiferal $\delta^{13} \mathrm{C}$ (top of each plot) and gradients (bottom of each plot) plotted with benthic foraminiferal $\delta^{18} \mathrm{O}$ offset records (bottom of each plot; gray) for same cores as Figure 3, with (a) records showing no temporal variations in benthic foraminiferal $\delta^{18} \mathrm{O}$ offset, (b) records showing small $\left(0.2-0.5 \%\right.$ ) temporal variations in benthic foraminiferal $\delta^{18} \mathrm{O}$ offset, and (c) records showing large $\left(>0.5 \%\right.$ ) temporal variations in benthic foraminiferal $\delta^{18} \mathrm{O}$ offset. All other records can be found in auxiliary material Figure S3 in Text S1. Data are from Sarnthein et al. [1994], Shackleton et al. [2000], and Schmiedl and Mackensen [2006]. 


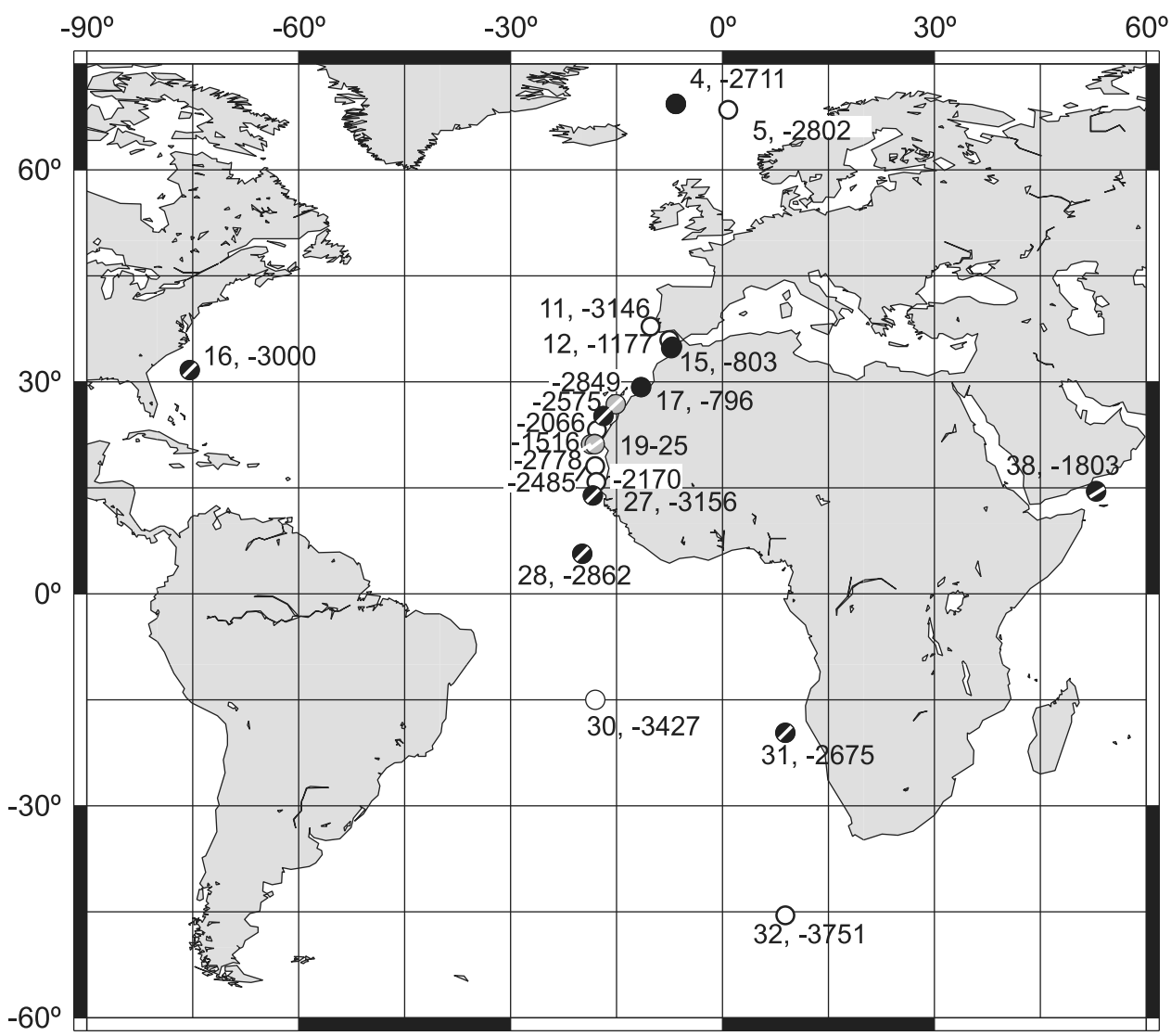

Figure 5. Overview of cores (and water depths) with $>15$ sample pairs and well-constrained age models, showing temporal (black and gray circles) or no temporal (white circles) variability in benthic foraminiferal $\delta^{18} \mathrm{O}$ offset for the last $<150,000$ years. Black and gray circles with a white bar represent cores where temporal variations in the $\delta^{18} \mathrm{O}$ offset between $C$. wuellerstorfi and $U$. peregrina and/or $U$. hollicki were detected. At GIK 12309 (19), GIK 16030 (22), and GIK 12328-5 (23) (gray circles with white bar), the glacial-interglacial offset variations are caused by depleted glacial U. peregrina $\delta^{18} \mathrm{O}$, whereas at KNR140-37JPC(16), GIK 12392-1(20), GIK 13239-1(27), GIK 13519 (28), V29-135 (31), and GeoB3004-1 (38) (black circles with white bar), the partly more negative interglacial offsets are caused by the Uvigerina species not showing the (full) deglacial/interglacial decrease in $\delta^{18} \mathrm{O}$.

coexisting benthic foraminiferal $\delta^{13} \mathrm{C}$ and $\delta^{13} \mathrm{C}$ offset records (remaining records are shown in auxiliary material Figure $\mathrm{S} 3$ in Text S1).

\section{Discussion}

\subsection{Causes for Temporal Changes in Benthic Foraminiferal $\delta^{18} \mathrm{O}$ Offsets}

[12] Differential bioturbation effects have been used to explain variations in benthic foraminiferal $\delta^{18} \mathrm{O}$ offsets, especially at low sedimentation rate locations [Zahn et al., 1986]. However, the intervals showing different benthic foraminiferal $\delta^{18} \mathrm{O}$ offsets in this work are between 0.2 and $1.3 \mathrm{~m}$ deep and generally exceed the typical length scales for bioturbation (Figure 3 and auxiliary material Figure S2 in Text S1) suggesting other causes may be responsible for the changes in benthic foraminiferal $\delta^{18} \mathrm{O}$ offsets. These include a change in dominant morphotype, although for morphotypes of $C$. wuellerstorfi from the east Timor Sea there appears to be no difference in either $\delta^{18} \mathrm{O}$ or $\delta^{13} \mathrm{C}$ [Dürkop et al., 2008].

[13] To test whether environmental settings are key to down-core coexisting benthic foraminiferal $\delta^{18} \mathrm{O}$ offsets, we focus our discussion on records that involve comparisons between $C$. wuellerstorfi versus $U$. peregrina and $U$. hollicki as these make up the majority of records (thirteen out of twenty records, with nine showing temporal variations) and involve more commonly used benthic foraminiferal species in paleoceanographic reconstruction. Comparison is made between records from the low-oxygen Arabian Sea, open Atlantic and the highly productive West African Margin (Figure 5).

[14] The average $\delta^{18} \mathrm{O}$ offsets between $C$. wuellerstorfi and the two Uvigerina species are identical (Table 1). Temporal offset variations between $C$. wuellerstorf $i$ versus $U$. peregrina and $U$. hollicki are the result of either: deglacial/ interglacial enrichment in Uvigerina (six records), or glacial depletion in Uvigerina (three records) (Figure 3 and auxiliary 

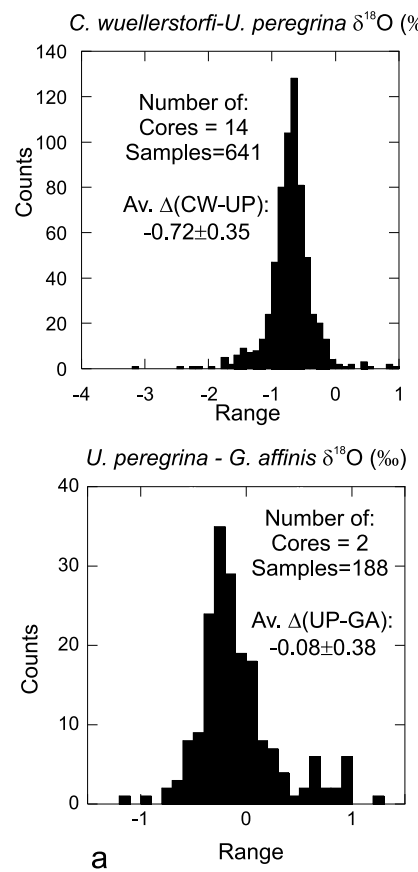
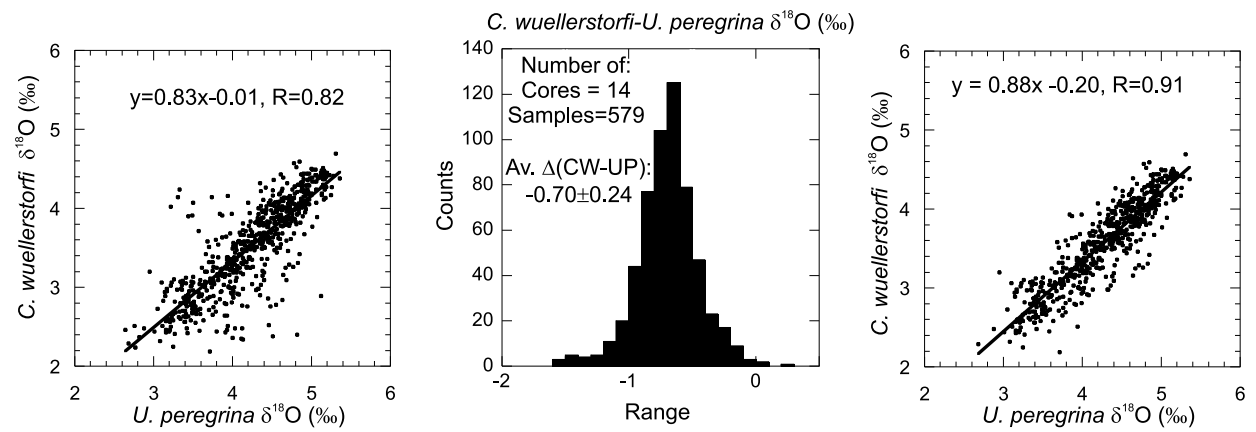

U. peregrina - G. affinis $\delta^{18} \mathrm{O}(\%)$
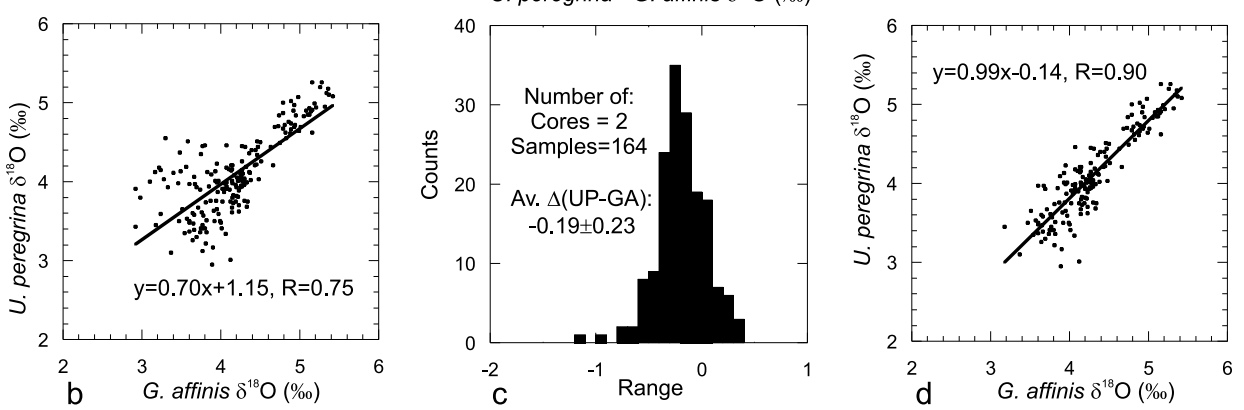

Figure 6. (a and c) Histograms of benthic foraminiferal $\delta^{18} \mathrm{O}$ offsets of original and edited C. wuellerstorfi versus $U$. peregrina and U. peregrina versus G. affinis and (b and d) crossplots. Exclusion of deglacial/ interglacial enriched $U$. peregrina and $G$. affinis samples and glacial depleted U. peregrina samples (in both cases where the difference in offset exceeded the standard deviation of the offset) reduces the standard deviation of the mean $\delta^{18} \mathrm{O}$ offset and improves the linear correlations (Figures $6 \mathrm{c}$ and $6 \mathrm{~d}$ ).

material Figure $\mathrm{S} 2$ in Text S1). Glacially depleted Uvigerina $\delta^{18} \mathrm{O}$ is only observed along the highly productive West African Margin, whereas deglacial/interglacial enrichments also occur in the low-oxygen Arabian Sea and open Atlantic Ocean (Figure 5). Clearly the deglacial/interglacial enrichment and glacial depletion in Uvigerina are due to secondary effects, including dissolution effects, metabolic fractionation, and/or kinetic fractionation.

[15] Dissolution effects seem unlikely; at Arabian Sea core GeoB3004-1, where the largest temporal offset variations occur between $C$. wuellerstorfi and $U$. peregrina, Schmiedl and Mackensen [2006] did not observe dissolution effects on recent $U$. peregrina, and there is no straightforward relation between $C$. wuellerstorfi-U. peregrina $\delta^{18} \mathrm{O}$ offset and calcite dissolution (see auxiliary material Figure S4 in Text S1). Changes in metabolic activity may affect isotope fractionation. Metabolic activity may be more intense in juveniles [Berger et al., 1978], or be increased under higher temperatures [Moberly, 1968], but the effects are unpredictable [Zhou and Zheng, 2003]. Most down-core dual benthic foraminiferal $\delta^{18} \mathrm{O}$ records are based on measurements of large adult specimens (see auxiliary material Table S1 in Text S1), and although warmer deepwater and intermediate water temperatures [Waelbroeck et al., 2002] during deglaciations/interglacials may have increased (infaunal) benthic foraminiferal metabolic activity, the noncoherent distribution of records characterized and uncharacterized by temporal offset changes (Figure 5) does not support a metabolic effect.
[16] Planktonic foraminiferal culture experiments show that decreasing (increasing) carbonate ion $\left(\mathrm{CO}_{3}^{2-}\right)$ concentrations cause an increase (decrease) in calcite $\delta^{18} \mathrm{O}$ and $\delta^{13} \mathrm{C}$ [Spero et al., 1997]. A similar effect has been proposed to influence benthic foraminifera $\delta^{18} \mathrm{O}$ and $\delta^{13} \mathrm{C}$ [Mackensen and Licari, 2004; Schmiedl et al., 2004], but this would require a much greater sensitivity to $\mathrm{CO}_{3}^{2-}$ than for planktonic foraminifera. For the records where the C. wuellerstorfi-Uvigerina $\delta^{18} \mathrm{O}$ offsets variations are caused by interglacial enrichment in Uvigerina (by 0.4 to $0.8 \%$ ) (Table 1), use of the $\mathrm{CO}_{3}^{2-}-\delta^{18} \mathrm{O}$ relationship of Spero et al. [1997] would result in large, and unrealistic, localized decreased deglacial/interglacial $\mathrm{CO}_{3}^{2-}$ of 200 to $400 \mu \mathrm{mol} / \mathrm{kg}$. For the records where the offset variations are caused by glacial depletion in Uvigerina $(-0.3$ to $1.2 \%$ ) unrealistic high glacial $\mathrm{CO}_{3}^{2-}$ (increased by 150 to $600 \mu \mathrm{mol} / \mathrm{kg}$ ) would be needed. A greater $(\times 4.5)$ sensitivity of benthic foraminiferal $\delta^{18} \mathrm{O}$ to $\mathrm{CO}_{3}^{2-}$ is confirmed by a recent study of Rathmann and Kuhnert [2008], based on recent $O$. umbonatus from core tops from the Namibian continental slope, and would result in more realistic pore water $\mathrm{CO}_{3}^{2-}$ changes of -111 to $-67 \mu \mathrm{mol} / \mathrm{kg}$ from the last glacial to interglacial to cause deglacial/interglacial enrichment in Uvigerina $\delta^{18} \mathrm{O}$, and +56 to $+155 \mu \mathrm{mol} / \mathrm{kg}$ to cause glacial depleted $\delta^{18} \mathrm{O}$ in Uvigerina. In the planktonic foraminiferal culture experiments calcite $\delta^{13} \mathrm{C}$ also increases with decreasing $\mathrm{CO}_{3}^{2-}$ [Spero et al., 1997], and so a similar effect may be expected in benthic foraminiferal $\delta^{13} \mathrm{C}$. Only two records (GIK13292-1, VIK13519-1) 
characterized by $\delta^{18} \mathrm{O}$ offset variations caused by deglacial/ interglacial enrichment in $U$. peregrina show contemporary interglacial $\delta^{13} \mathrm{C}$ enrichments (up to $0.8 \%$ ) compared with C. wuellerstorfi, whereas the remaining records show $\delta^{13} \mathrm{C}$ depletion or no effect (Figure 4 and auxiliary material Figure S4 in Text S1). In the low-oxygen Arabian Sea $\delta^{18} \mathrm{O}$ offset variations resulting from deglacial/interglacial ${ }^{18} \mathrm{O}$ enriched $U$. peregrina, have been linked to increased remineralization of organic material during interglacials [Schmiedl and Mackensen, 2006; Gupta et al., 2008]. One possible explanation for an absence of deglacial $\delta^{13} \mathrm{C}$ enrichment in Uvigerina $\delta^{13} \mathrm{C}$ and perhaps even depletion at higher-productivity locations could be related to high remineralization rates of organic material causing increased release of light ${ }^{12} \mathrm{C}$ and decrease in benthic foraminiferal $\delta^{13} \mathrm{C}$, thus counteracting the $\delta^{13} \mathrm{C}$ increase caused by the inferred $\mathrm{CO}_{3}^{2-}$ decrease.

[17] For the other records from the West African Margin where the offset variations are caused by glacially depleted Uvigerina $\delta^{18} \mathrm{O}$ (e.g., GIK 16030-1, GIK 12328-5 and GIK 12309-1), increased glacial $\mathrm{CO}_{3}^{2-}$ concentrations would be needed. Glacial Atlantic intermediate water $\mathrm{CO}_{3}^{2-}$ may have been increased, but the deeper sites (GIK12328-5 and GIK12309-1) were likely bathed in low- $\mathrm{CO}_{3}^{2-}$ Glacial Antarctic Bottom Waters [Curry and Oppo, 2005; Sarnthein et al., 1994; Yu et al., 2008]. In the present-day northeast Arabian Sea $U$. peregrina specimens living inside bacterial mats within the oxygen minimum zone have depleted $\delta^{18} \mathrm{O}$ values compared with specimens living outside the mat [Erbacher and Nelskamp, 2006]. Perhaps similar environmental conditions are responsible for depleted glacial $U$. peregrina $\delta^{18} \mathrm{O}$ off West Africa. In both cases (bacterial mats, glacial West African Margin), depleted Uvigerina $\delta^{18} \mathrm{O}$ was not accompanied by depleted $\delta^{13} \mathrm{C}$ (in fact no effect was observed in the West African Margin records, even though productivity and export were enhanced during the last glacial [Abrantes, 2000; Kohfeld et al., 2005]), providing support for the idea that similar mechanism may be responsible for the depletions in $\delta^{18} \mathrm{O}$. In-depth multiproxy research (down-core and culturing) is needed to assess the potential role of seawater $\mathrm{CO}_{3}^{2-}$, metabolic and other effects on (infaunal) benthic foraminiferal $\delta^{18} \mathrm{O}$.

\subsection{Implications}

[18] This review reveals relatively large variability in benthic foraminiferal $\delta^{18} \mathrm{O}$ offsets (standard deviations between 0.22 to $0.66 \%$, which is significantly larger than analytical (external, i.e., including sample gas generation plus instrumental precision) reproducibility of isotope analysis that typically is better than $\sim 0.08 \%$ o). This may affect the interpretation of composite records based on multiple benthic foraminiferal species, and comparison of records from different locations that were measured using different monospecific benthic foraminiferal species or composite records, where a constant adjustment is made.

[19] Relatively large uncertainties may therefore be added to studies using composite benthic foraminiferal $\delta^{18} \mathrm{O}$ records to infer sea level changes, and deepwater temperatures. Taking a standard deviation of $0.2 \%$ of the $\delta^{18} \mathrm{O}$ offset between benthic foraminiferal species into account potentially contributes $25 \mathrm{~m}$ uncertainty to sea level reconstructions and a $\sim 1{ }^{\circ} \mathrm{C}$ uncertainty to deepwater temperature reconstructions). Exclusion of suspect deglacial/ interglacial and glacial outliers improves the linear correlation between $\delta^{18} \mathrm{O}$ pairs of $C$. wuellerstorfi versus $U$. peregrina and $U$. peregrina versus $G$. affinis and reduces their mean $\delta^{18} \mathrm{O}$ offset standard deviations (Figure 6). Standard deviations of $\delta^{18} \mathrm{O}$ offsets between species along a single sediment core are lower on occasion although the majority fall close to $0.2 \%$ (Table 1 ). In order to minimize uncertainties it is recommended to use locally derived benthic foraminiferal offsets for the construction of multispecies benthic foraminiferal $\delta^{18} \mathrm{O}$ records.

[20] The majority of down-core records examined display temporal variations in benthic foraminiferal $\delta^{18} \mathrm{O}$ offsets (Figure 5). These occur for paired epifaunal-epifaunal, epifaunal-infaunal, and infaunal-infaunal benthic foraminiferal $\delta^{18} \mathrm{O}$ at a wide range $(800-4000 \mathrm{~m})$ of water depths (Table 1 and Figure 5). All down-core benthic foraminiferal $\delta^{18} \mathrm{O}$ offset records are from the Atlantic (19 records) and Indian Ocean (1 record) (Figure 5); isotope records from the Pacific contained only a small number of $(>15) \delta^{18} \mathrm{O}$ pairs for the last 150,000 years that was insufficient to robustly assess $\delta^{18} \mathrm{O}$ variability through time between different benthic species.

[21] The finding of temporal changes in interspecies $\delta^{18} \mathrm{O}$ offsets has potential stratigraphic implications. Not knowing $\delta^{18} \mathrm{O}$ enrichments within parts of monospecific $U$. peregrina $\delta^{18} \mathrm{O}$ records may add uncertainty to the identification of Marine Isotope Stage boundaries and hinder the core-tocore correlation of finer-scale (sub-Milankovich) variability along benthic $\delta^{18} \mathrm{O}$ records. Variations through time of interspecific benthic $\delta^{18} \mathrm{O}$ also bear implications for sea level, deepwater temperature, and local deepwater $\delta^{18} \mathrm{O}$ reconstructions. Variable $\delta^{18} \mathrm{O}$ enrichment in benthic foraminiferal tests due to changing seawater carbonate chemistry $\left(\mathrm{CO}_{3}^{2-}\right)$ constitutes a further uncertainty that potentially affects the paleohydrographic interpretation of benthic $\delta^{18} \mathrm{O}$ records. Hence benthic foraminiferal $\delta^{18} \mathrm{O}$ offset variations and variable $\delta^{18} \mathrm{O}$ enrichment in individual benthic species needs to be considered when interpreting monospecific infaunal and in particular, composite multiple-species benthic foraminiferal $\delta^{18} \mathrm{O}$ records.

\section{Conclusions}

[22] The hypothesis that benthic foraminiferal $\delta^{18} \mathrm{O}$ offsets of widely used benthic foraminiferal species are constant is tested using existing isotope data covering the last glacial-interglacial cycle.

[23] Of the twenty down-core $\delta^{18} \mathrm{O}$ offset records investigated, twelve showed significant temporal offset variations (exceeding the offset standard deviation) that are not related to short-term random variability. These temporal changes in benthic foraminiferal offsets may be related to kinetic fractionation effects, with changes in pore water $\mathrm{CO}_{3}^{2-}$, leading to $\delta^{18} \mathrm{O}$ enrichment and depletion in infaunal species, but this mechanism needs to be confirmed by further research. Temporal $\delta^{18} \mathrm{O}$ enrichment and depletion in mainly infaunal 
species can have implications for stratigraphy and estimates of sea level, deepwater temperature and local deepwater $\delta^{18} \mathrm{O}$ studies.
[24] Acknowledgments. This research was funded by Quaternary Quest (NERC). Careful and critical reviews by F. Jorissen, two anonymous reviewers, and the editor (R. Zahn) significantly improved the contents of this paper.

\section{References}

Abrantes, F. (2000), 200,000 yr diatom records from Atlantic upwelling sites reveal maximum productivity during LGM and shift in phytoplankton community structure at 185,000 yr, Earth Planet. Sci. Lett., 176, 7-16, doi:10.1016/S0012-821X(99)00312-X.

Bauch, H. A., H. Erlenkeuser, R. F. Spielhagen, U. Struck, J. Matthiessen, J. Thiede, and J. Heinemeier (2001), A multiproxy reconstruction of the evolution of deep and surface waters in the subarctic Nordic seas over the last 30,000 years, Quat. Sci. Rev., 20, 659-678, doi:10.1016/S0277-3791(00)00098-6.

Bemis, B. E., H. J. Spero, J. Bijma, and D. W. Lea (1998), Re-evaluation of the oxygen isotopic composition of planktonic foraminifera: Experimental results and revised temperature equations, Paleoceanography, 13, 150-160, doi:10.1029/98PA00070.

Berger, W. H., J. S. Killingley, and E. Vincent (1978), Stable isotopes in deep sea carbonates: Box core ERDC 92 west equatorial Pacific, Oceanol. Acta, 1, 203-216.

Berger, W. H., J. S. Killingley, C. V. Metzler, and E. Vincent (1985), Two-step deglaciation: ${ }^{14} \mathrm{C}$-dated high-resolution $\delta^{18} \mathrm{O}$ records from the tropical Atlantic Ocean, Quat. Res., 23, 258-271, doi:10.1016/0033-5894(85)90032-8.

Bijma, J., H. J. Spero, and D. W. Lea (1999), Reassessing foraminiferal stable isotope geochemistry: Impact of the ocean carbonate system (experimental results), in Use of Proxies in Paleoceanography: Examples From the South Atlantic, edited by G. Fischer and G. Wefer, pp. 489-512, Springer, Berlin.

Broecker, W. S., and T. H. Peng (1982), Tracers in the Sea, 690 pp., Columbia Univ., New York.

Bühring, C. (2001), East Asian Monsoon variability on orbital- and millennial-to-sub-decadal time scales, Ph.D. thesis, 164 pp., Math.-Naturwiss. Fak. der Christian-Albrechts-Univ. zu Kiel, Kiel, Germany.

CLIMAP Project Members (1981), Seasonal reconstruction of the Earth's surface at the last glacial maximum, Map Chart Ser. MC-36, Geol. Soc. of Am., Boulder, Colo.

Curry, W. B., and D. W. Oppo (2005), Glacial water mass geometry and the distribution of $\delta^{13} \mathrm{C}$ of $\Sigma \mathrm{CO}_{2}$ in the western Atlantic Ocean, Paleoceanography, 20, PA1017, doi:10.1029/ 2004PA001021.

Curry, W. B., J. C. Duplessy, L. D. Labeyrie, and N. J. Shackleton (1988), Changes in the distribution of $\delta^{13} \mathrm{C}$ of deep water $\Sigma \mathrm{CO}^{2}$ between the last glaciation and the Holocene, Paleoceanography, 3, 317-341, doi:10.1029/ PA003i003p00317.

Duplessy, J.-C. (1996), Quaternary paleoceanography: Unpublished stable isotope records, IGBP PAGES/World Data Cent. for Paleoclimatol. Data Contrib. Ser., 1996-035, NGDC Paleoclimatol. Program, NOAA, Boulder, Colo.

Duplessy, J. C., C. Lalou, and A. C. Vinot (1970), Differential isotopic fractionation in benthic foraminifera and paleotemperatures assessed, Science, 168, 250-251, doi:10.1126/ science.168.3928.250.

Duplessy, J. C., L. Labeyrie, and P. L. Blanc (1988), Norwegian Sea Deep Water variations over the last climatic cycle: Paleooceanographical implications, in Long and Short Term Variability of Climate, edited by $\mathrm{H}$. Wanner and U. Siegenthaler, pp. 83-116, Springer, Heidelberg, Germany, doi:10.1007/ BFb0046591.

Dürkop, A., A. Holbourn, W. Kuhnt, R. Zuraida, N. Andersen, and P. M. Grootes (2008), Centennial-scale climate variability in the Timor Sea during Marine Isotope Stage 3, Mar. Micropaleontol., 66, 208-221, doi:10.1016/j. marmicro.2007.10.002.

Erbacher, J., and S. Nelskamp (2006), Comparison of benthic foraminifera inside and outside a sulphur-oxidizing bacterial mat from the present oxygen-minimum zone off Pakistan (NE Arabian Sea), Deep Sea Res., Part I, 53, 751-775, doi:10.1016/j.dsr.2006.02.003.

Fontanier, C., A. Mackensen, F. J. Jorissen, P. Anschultz, L. Licari, and C. Griveaud (2006), Stable oxygen and carbon isotopes of live benthic foraminifera from the Bay of Biscay: Microhabitat impact and seasonal variability, Mar. Micropaleontol., 58, 159-183, doi:10.1016/ j.marmicro.2005.09.004

Gupta, A. K., M. Das, S. C. Clemens, and B. Mukherjee (2008), Benthic foraminiferal faunal and isotopic changes as recorded in Holocene sediments of the northwest Indian Ocean, Paleoceanography, 23, PA2214, doi:10.1029/2007PA001546.

Hagen, S., and L. D. Keigwin (2002), Sea-surface temperature variability and deep water reorganisation in the subtropical North Atlantic during Isotope Stage 2-4, Mar. Geol., 189, 145-162, doi:10.1016/S0025-3227(02)00327-4.

Hodell, D. A., C. D. Charles, J. H. Curtis, P. G. Mortyn, U. S. Ninnemann, and K. Venz (2003), Data report: Calcareous nannofossil data from the Eocene to Oligocene, Leg 177 , Hole 1090B, Proc. Ocean Drill. Program Sci. Results, 177, 1-26.

Kim, S. T., and J. R. O’Neil (1997), Equilibrium and non-equilibrium oxygen isotope effects in synthetic calcites, Geochim. Cosmochim. Acta, 33, 1-17.

Kohfeld, K. E., C. Le Quéré, S. P. Harrison, and R. F. Anderson (2005), Role of marine biology in glacial-interglacial $\mathrm{CO}_{2}$ cycles, Science, 308, 74-78, doi:10.1126/science.1105375.

Labeyrie, L., and J. C. Duplessy (1985), Changes in the oceanic ${ }^{13} \mathrm{C} /{ }^{12} \mathrm{C}$ ratio during the last 140,000 years: High latitude surface water records, Palaeogeogr. Palaeoclimatol. Palaeoecol., 50, 217-240.

Labeyrie, L., et al. (1995), Surface and deep hydrology of the northern Atlantic Ocean during the last 150,000 years, Philos. Trans. R. Soc. London, Ser. B, 348, 255-264, doi:10.1098/rstb.1995.0067.

Labeyrie, L., et al. (1996), Hydrographic changes of the Southern Ocean (southeast Indian sector) over the last $230 \mathrm{kyr}$, Paleoceanography, 11 57-76, doi:10.1029/95PA02255.

Mackensen, A., and L. Licari (2004), Carbon isotopes of live benthic foraminifera from the South Atlantic: Sensitivity to bottom water carbonate saturation state and organic matter rain rates, in The South Atlantic in the Late Quaternary: Reconstruction of Material Budget and Current Systems, edited by G. Wefer, S. Mulitza, and V. Rathmeyer, pp. 623-644, Springer, Berlin.

Mackensen, A., H. W. Hubberten, T. Bickert, G. Fischer, and D. K. Futterer (1993), The $\delta^{13} \mathrm{C}$ in benthic foraminiferal tests of Fontbotia wuellerstorfi (Schwager) relative to $\delta^{13} \mathrm{C}$ of dissolved inorganic carbon in Southern Ocean Deep Water: Implications for glacial ocean circulation models, Paleoceanography, 8 , 587-610, doi:10.1029/93PA01291.

McCorkle, D. C., L. D. Keigwin, B. H. Corliss, and S. R. Emerson (1990), The influence of microhabitats on the carbon isotopic composition of deep-sea benthic foraminifera, Paleoceanography, 5, 161-185, doi:10.1029/ PA005i002p00161

Moberly, R. (1968), Composition of magnesium calcites algae and pelecypods by electron microprobe analysis, Sedimentology, 11, 61-82, doi:10.1111/j.1365-3091.1968.tb00841.x.

Rathmann, S., and H. Kuhnert (2008), Carbonate ion effect on $\mathrm{Mg} / \mathrm{Ca}, \mathrm{Sr} / \mathrm{Ca}$ and stable isotopes on the benthic foraminifera Oridorsalis umbonatus off Namibia, Mar. Micropaleontol., 66, 120-133, doi:10.1016/j.marmicro.2007.08.001. Sarnthein, M., K. Winn, S. A. Jung, J. C. Duplessy, L. Labeyrie, H. Erlenkeusser, and G. Ganssen (1994), Changes in east Atlantic deepwater circulation over the last 30,000 years: Eight time slice reconstructions, Paleoceanography, 9, 209-267, doi:10.1029/93PA03301.

Sarnthein, M., et al. (2001), Fundamental modes and abrupt changes in North Atlantic circulation and climate over the last $60 \mathrm{ky}$-Concepts, reconstruction and numerical modeling, in The Northern North Atlantic: A Changing Environment, edited by W. Schäfer et al., pp. 365-410, Springer, Berlin.

Schmiedl, G., and A. Mackensen (2006), Multispecies stable isotopes of benthic foraminifers reveal past changes of organic matter decomposition and deepwater oxygenation in the Arabian Sea, Paleoceanography, 21 PA4213, doi:10.1029/2006PA001284.

Schmiedl, G., M. Pfeilsticker, C. Hemleben, and A. Mackensen (2004), Environmental and biological effects on the stable isotope composition of recent deep-sea benthic foraminifera from the western Mediterranean Sea, Mar. Micropaleontol., 51, 129-152, doi:10.1016/ j.marmicro.2003.10.001.

Shackleton, N. J. (1974), Attainment of isotopic equilibrium between ocean water and benthonic foraminifera genus Uvigerina: Isotopic changes in the ocean during the last glacial, in Variation du Climat au Cours du Pleistoceene, edited by L. Labeyrie, Colloq. Int. Cent. Natl. Rech. Sci., 219, 203-209. 
Shackleton, N. J., M. Hall, and E. Vincent (2000), Phase relationships between millennial-scale events 64,000-24,000 years ago, Paleoceanography, 15, 565-569, doi:10.1029/ 2000PA000513.

Shackleton, N. J., R. G. Fairbanks, T.-C. Chiu, and F. Parrenin (2004), Absolute calibration of the Greenland time scale: Implications for Antarctic time scales and for $\Delta^{14} \mathrm{C}$, Quat. Sci. Rev., 23, 1513-1522, doi:10.1016/ j.quascirev.2004.03.006.

Spero, H. J., J. Bijma, D. W. Lea, and B. E. Bemis (1997), Effect of seawater carbonate concentration on foraminiferal carbon and oxygen isotopes, Nature, 390, 497-500, doi:10.1038/ 37333

Voelker, A. H. L., M. Sarnthein, P. M. Grootes, H. Erlenkeuser, C. Laj, A. Mazaud, M. J. Nadeau, and M. Schleicher (1998), Correlation of marine ${ }^{14} \mathrm{C}$-ages from the Nordic Seas with the GISP2 isotope record: Implications for radiocarbon calibration beyond $25 \mathrm{ka}$ BP, Radiocarbon, 40, 517-534.

Voelker, A., S. M. Lebreiro, J. Schönfeld, I. Cacho, H. Erlenkeuser, and F. Abrantes (2006), Mediterranean outflow strengthening during northern hemisphere coolings: A salt source for the glacial Atlantic?, Earth Planet. Sci. Lett., 245, 39-55, doi:10.1016/j.epsl.2006.03.014.

Vogelsang, E. (1990), Paläo-Ozeanographie des Europäischen Nordmeeres an Hand stabiler Kohlenstoff- und Sauerstoffisotope, Ber. Sonderforschungsber. 313, 23, 136 pp., Christian-Albrechts-Univ. zu Kiel, Kiel, Germany.

Waelbroeck, C., L. Labeyrie, E. Michel, J. C. Duplessy, J. F. McManus, K. Lambeck,
E. Balbon, and M. Labracherie (2002), Sealevel and deep water temperature changes derived from benthic foraminifera isotopic records, Quat. Sci. Rev., 21, 295-305, doi:10.1016/S0277-3791(01)00101-9.

Wang, L., M. Sarnthein, H. Erlenkeuser, J. O Grimalt, P. M. Grootes, S. Heilig, E. V. Ivanova M. Kienast, C. Pelejero, and U. Pflaumann (1999), East-Asian monsoon climate during the Late Pleistocene: High-resolution sedimen records from the South China Sea, Mar. Geol. 156, 245-284, doi:10.1016/S0025-3227(98) $00182-0$.

Weinelt, M. (1993), Veränderungen der Oberflächenzirkulation im Europäischen Nordmeer während der letzten 60.000 Jahre - Hinweise aus stabilen Isotopen, Ber. Sonderforschungsber. 313, 41, 106 pp., Christian-Albrechts-Univ. zu Kiel, Kiel, Germany.

Winn, K., M. Sarnthein, and H. Erlenkeuser (1991), ${ }^{18} \mathrm{O}$ stratigraphy and chronology of Kiel sediment cores from the east Atlantic, Ber. Geol.-Paläontol. Inst. Mus., 45, 99 pp., Christian-Albrechts-Univ. zu Kiel, Kiel, Germany.

Wollenburg, J. E., W. Kuhnt, and A. Mackensen (2001), Changes in Arctic Ocean paleoproductivity and hydrography during the last $145 \mathrm{kyr}$ : The benthic foraminiferal record, Paleoceanography, 16, 65-77, doi:10.1029/1999PA000454.

Woodruff, F., S. M. Savin, and R. G. Douglas (1980), Biological fractionation of oxygen and carbon isotopes by recent benthic foraminifera, Mar. Micropaleontol., 5, 3-11, doi:10.1016/ 0377-8398(80)90003-1.

Yu, J., H. Elderfield, and A. M. Piotrowski (2008), Seawater carbonate ion- $\delta{ }^{13} \mathrm{C}$ systematics and application to glacial-interglacial North Atlantic ocean circulation, Earth Planet. Sci. Lett., 271, 209-220, doi:10.1016/j.eps1.2008.04.010.

Zahn, R., K. Winn, and M. Sarnthein (1986),

Benthic foraminiferal $\delta^{13} \mathrm{C}$ and accumulation rates of organic carbon: Uvigerina peregrina group and Cibicidoides wuellerstorfi, Paleoceanography, 1, 27-42, doi:10.1029/ PA001i001p00027.

Zahn-Knoll, R. (1986), Spätquartäre Entwicklung von Küstenauftrieb und Tiefenwasserzirkulation im Nordost-Atlantik. Rekonstruktion anhand stabiler Isotope kalkschaliger Foraminiferen, diploma thesis, 111 pp., Geol.-Paläontol. Inst. Christian-Albrechts-Univ. zu Kiel, Kiel, Germany.

Zeebe, R. (1999), An explanation of the effect of seawater carbonate concentration on foraminiferal oxygen isotopes, Geochim. Cosmochim. Acta, 63, 2001-2007, doi:10.1016/S0016-7037 (99)00091-5.

Zhou, G. T., and Y. F. Zheng (2003), An experimental study of oxygen isotope fractionation between inorganically precipitated aragonite and water at low temperatures, Geochim. Cosmochim. Acta, 67, 387-399 doi:10.1016/S0016-7037(02)01140-7.

S. Crowhurst, H. Elderfield, and B. Hoogakker, Department of Earth Sciences, University of Cambridge, Downing Street, Cambridge CB2 3EQ, UK. (bhoo03@esc.cam.ac.uk)

K. Oliver, Southampton School of Ocean and Earth Sciences, University of Southampton, European Way, Southampton SO14 3ZH, UK. 